\title{
Marktconvergentie en alliantievorming in de Nederlandse telecommunicatie- en
} media-industrie

\section{Nadine Roijakkers, Ard-Pieter de Man en Ivo Gubbels}

\begin{abstract}
SAMENVATTING Dankzij digitalisering en liberalisering ontstaat convergentie tussen voorheen gescheiden sectoren. Deze convergentie kan organisatorisch onder meer gerealiseerd worden door het gebruik van allianties. Dit artikel onderzoekt hoe een bepaald type convergentie wordt gerealiseerd met behulp van verschillende allianties. Wij concluderen dat allianties inderdaad worden ingezet voor convergentie, dat convergentie plaatsvindt tussen bestaande markten en rondom creatie van nieuwe markten, maar dat geen verschillende alliantievormen worden gebruikt voor deze twee vormen van marktconvergentie.
\end{abstract}

\section{RELEVANTIE VOOR DE PRAKTIJK Allianties zijn een nuttig middel om convergentie rondom markten te realiseren. Zij kunnen zowel worden ingezet wanneer het gaat om convergentie rondom bestaande markten als bij convergentie rondom nieuwe markten. Dit geeft flexibiliteit en vermindering van risico's, zonder dat middelen op de lange termijn hoeven te worden vastgelegd.}

\section{Inleiding}

In de academische literatuur zijn verschillende definities van convergentie te vinden (zie bijvoorbeeld Von Tunzelmann, 1988; Lant en Mezias, 1992; Yoffie, 1997; Bauer, 2005). Ondanks deze verscheidenheid aan opvattingen, hebben alle omschrijvingen een element van vervlechting in zich. Convergentie betekent het vervagen van grenzen tussen voorheen gescheiden technologieën, markten en organisaties. Grofweg kunnen we in de literatuur drie tijdsperioden onderscheiden waarin wetenschappers de nadruk leggen op verschillende aspecten van het begrip convergentie: de jaren tachtig van de vorige eeuw waarin de focus ligt op technologische convergentie, de jaren negentig van de vorige eeuw waarin onderzoekers zich vooral richten op het bestuderen van dienst/marktconvergentie en het eerste decennium van de huidige eeuw waarin organisatorische convergentie centraal staat. Dit artikel onderzoekt of twee subvormen van marktconvergentie zich voordoen in de Nederlandse telecom- en mediasector en of zij daarbij allianties gebruiken om die marktconvergentie organisatorisch te realiseren.

Organisatorische convergentie kan gerealiseerd worden door fusie en overname en door allianties. De literatuur heeft zich voornamelijk op fusie en overname gericht (Chan-Olmsted, 1998; Chon et al., 2003), maar er zijn ook verscheidene artikelen verschenen die handelen over de rol van allianties in convergentie. De meeste van deze artikelen bestuderen de convergentie tussen hoogtechnologische industrieën zoals de internationale IT-sectoren (Duysters en Hagedoorn, 1998; Chan-Olmsted en Jamison, 2001; Borés, Saurina en Torres, 2003; Lee, 2007). Allianties zijn samenwerkingsverbanden tussen bedrijven waarbij twee of meerdere partners een gezamenlijk doel nastreven. Deze samenwerkingsverbanden zijn strategisch van aard en maken gebruik van de complementaire capaciteiten van de betrokken partners. Allianties kunnen verschillende vormen aannemen, afhankelijk van onder andere de mate van investering die met de samenwerking gemoeid is. Aan de hand van dit criterium onderscheiden we twee hoofdcategorieën van allianties: non-equity allianties (bijvoorbeeld contractuele allianties) en equity allianties, waarmee aandelenverhoudingen gemoeid zijn, bijvoorbeeld joint ventures (De Jong en Kleijn, 2009) en minderheidsdeelnemingen.

De vraag of verschillende typen allianties (equity versus non-equity) een verschillende rol spelen in verschillende typen marktconvergentie, is nog niet beantwoord. Wordt 
marktconvergentie organisatorisch vormgegeven via equity allianties of via non-equity allianties? Dit artikel wil een begin maken met het beantwoorden van die vraag, door een onderzoek naar convergentie tussen de Nederlandse telecommunicatie- en media-industrie. Daarbij onderscheiden we twee typen marktconvergentie: convergentie van bestaande markten en marktcreatie.

Over de recente convergentie tussen de Nederlandse telecommunicatie- en media-industrie en het belang van samenwerkingsverbanden in deze ontwikkelingen is nog relatief weinig geschreven. Dat deze sectoren gekenmerkt worden door convergentie, staat buiten kijf. Recentelijk verscheen er in opdracht van de OPTA (Onafhankelijke Post en Telecommunicatie Autoriteit) een rapport van het onderzoeksbureau RAND over convergentie en de te volgen strategieën door beleidsorganen (Van Oranje et al., 2008). Het rapport beschrijft het belang van digitalisering en liberalisering in de convergentie. In het bijzonder digitalisering (en de consequenties hiervan voor verwerkingssnelheid, opslagcapaciteit en transmissiesnelheid) heeft ervoor gezorgd dat verschillende diensten via dezelfde infrastructuur kunnen worden overgebracht. Ook is het tegenwoordig mogelijk om een dienst of een pakket met diensten te verspreiden via verschillende infrastructuren (zoals kabel, satelliet en telecommunicatienetwerken). Deze gerelateerde processen van technologische convergentie en dienstconvergentie hebben er toe geleid dat bedrijven in de telecommunicatie- en media-industrie hun samengesmolten markten in toenemende mate gezamenlijk bedienen met geïntegreerde dienstverlening.

Telecommunicatiebedrijven en mediabedrijven gebruiken hun allianties om bestaande dienstverlening te versterken of uit te breiden. Voorbeelden hiervan zijn e-mail of internet via mobiele telefoons en televisie of video via internet. Naast convergentie in bestaande markten en dienstverlening zien we ook de creatie van geheel nieuwe markten die met nieuwe diensten zoals video-op-aanvraag worden bediend. Ook in deze marktcreatie spelen allianties een belangrijke rol.

In de volgende paragraaf beschrijven we eerst wat convergentie precies inhoudt, wat de oorzaken van convergentie zijn en welke vormen van convergentie te onderscheiden zijn. Daarna zullen we ons richten op een beschrijving van verschillende typen allianties en de rol die deze samenwerkingsverbanden spelen in convergentie. De navolgende paragrafen geven een overzicht van de telecommunicatieen media-industrie en de verzamelde data op basis waarvan convergentie in deze sectoren geanalyseerd wordt. In de laatste twee paragrafen lichten we de data-analyse toe en trekken we conclusies op basis van deze analyse.

\section{Convergentie: definitie, vormen en oorzaken}

Wanneer men de term convergentie opzoekt in de Nederlandse Van Dale, vindt men de volgende definitie: toenadering naar één punt. Het begrip convergentie wordt voornamelijk gebruikt in de chemie, wiskunde en specifieke onderdelen van de internationale economie; in de bedrijfskunde zijn relatief weinig artikelen verschenen die handelen over convergentie. Een van de eerste bedrijfskundige artikelen waarin de term convergentie gebruikt wordt, is de publicatie van Porter en Millar (1985). Zij beschrijven technologische convergentie in de informatietechnologie en stellen een aantal strategieën voor die bedrijven in staat stellen hiermee om te gaan. De eerste (en later veel gebruikte) ideeën over technologische convergentie zijn afkomstig van Nicholas Negroponte, de grondlegger en voorzitter van MIT's Media Lab, begin jaren tachtig van de vorige eeuw. De theorie van Negroponte gaat ervan uit dat de televisie-industrie, de uitgeverij en de computerindustrie steeds meer zullen vervlechten, waarbij een multimedia-infrastructuur wordt gecreëerd.

Er bestaat geen algemeen geaccepteerde definitie van het begrip. Sterker nog, er wordt een grote verscheidenheid aan definities gehanteerd in het beperkte aantal academische artikelen dat tot nu toe over convergentie is verschenen (zie bijvoorbeeld Von Tunzelmann, 1988; Lant en Mezias, 1992; Yoffie, 1997; Gambardella en Malerba, 1999; Wirtz, 2001; Bauer, 2005). Ondanks hun uiteenlopende focus handelen bijna alle artikelen over convergentie in de zin van samensmelting tussen technologieën, markten en organisaties, waarbij voorheen sterk afgebakende grenzen steeds meer vervagen.

De belangrijkste oorzaken van convergentie zijn te herleiden tot technologische ontwikkelingen, voornamelijk digitalisering en verminderde interventie door overheden als gevolg van liberalisering (zie Wirtz, 2001; Van Oranje et al., 2008). Door digitalisering is het mogelijk geworden om verschillende diensten via dezelfde infrastructuur te verspreiden. Ook kan een bepaalde dienst tegenwoordig worden overgebracht via verschillende infrastructuren. Digitalisering heeft bovendien geleid tot een hogere verwerkingssnelheid, opslagcapaciteit en transmissiesnelheid. Een tweede belangrijke oorzaak van convergentie is liberalisering. In de Verenigde Staten heeft zich in de tweede helft van de jaren negentig van de vorige eeuw een ingrijpend proces van deregulatie voltrokken in de media- en communicatie-industrie. Hierdoor werd het voor bedrijven eenvoudiger om concurrerende markten te betreden en om partijen hoger of lager in de waardeketen over te nemen. In de Europese Unie heeft zich een soortgelijk proces voltrokken. Zo is de telecommunicatiesector in de afgelopen jaren bijna volledig geliberaliseerd. Als gevolg 
hiervan zijn de voorwaarden om te kunnen concurreren ook in de Europese markt sterk veranderd (Wirtz, 2001). In de volgende paragrafen zullen we de verschillende, aan elkaar gerelateerde, vormen van convergentie bespreken.

\subsection{De jaren tachtig van de vorige eeuw: technologische convergentie}

De eerste bedrijfskundige publicaties over technologische convergentie dateren uit de jaren tachtig van de vorige eeuw. Hoewel een van de eerste artikelen op dit gebied zijn oorsprong vindt in strategisch management (Porter en Millar, 1985), is het grootste gedeelte van de verschenen literatuur over technologische convergentie gebaseerd op Schumpeteriaanse innovatietheorie en de evolutionaire economie. Wetenschappers probeerden de ingrijpende technologische veranderingen die zich in een aantal hoogtechnologische industrieën begonnen te voltrekken, te verklaren (zie bijvoorbeeld Charles, Monk en Sciberras, 1989; De Jonquieres, 1989). Zij beschreven deze veranderingen als een proces van technologische convergentie, waarbij digitale technologie de basis zou gaan vormen voor samenhangende technologische ontwikkelingen in een groot aantal sectoren. Op basis van deze gedeelde technologische infrastructuur zouden deze industrieën steeds meer naar elkaar toegroeien.

Vooral in de tweede helft van de jaren tachtig van de vorige eeuw voorspelden veel wetenschappers de technologische convergentie tussen de telecommunicatie-industrie en de computerindustrie. Deze voorspelling was gebaseerd op het feit dat de telecommunicatiesector in toenemende mate geautomatiseerd werd, terwijl de toepassing van netwerktechnologie in de computerindustrie zorgde voor een verhoogde inter-connectie tussen computers. Dit leidde ertoe dat de telecommunicatie- en computerindustrie gebruik gingen maken van een gedeelde infrastructuur en dat vormde een belangrijke aanleiding voor een aantal grote spelers in de betrokken sectoren (zoals Alcatel, GEC, Olivetti, AT\&T en Siemens) om hun technologische activiteiten te diversifiëren. Een van de weinige empirische studies die zijn uitgevoerd naar het succes van deze technologische diversificatie in de computer- en telecommunicatie-industrie is het onderzoek van Von Tunzelmann en Soete (1987; Von Tunzelmann, 1988). Zij concludeerden dat het proces van technologische convergentie weinig effect had op de ontwikkeling van de kerncapaciteiten van grote computer- en telecommunicatiebedrijven.

\subsection{De jaren negentig van de vorige eeuw: dienst/ marktconvergentie}

De basis voor de tweede stroming binnen de convergentieliteratuur is nog steeds het uitgangspunt dat digitalisering de technologische grondslag vormt van meerdere industrieën.
Door deze gezamenlijke technologische basis is het mogelijk geworden om een willekeurige dienst te verspreiden via verschillende fysieke infrastructuren (zoals kabel-, satellieten telecommunicatienetwerken). Echter, in publicaties die gedurende de jaren negentig zijn verschenen (zie bijvoorbeeld Bresnahan en Saloner, 1997; European Commission, 1997; Greenstein en Khanna, 1997; McGahan, Vadasz en Yoffie, 1997; Gambardella en Torrisi, 1998), lag de nadruk niet meer zozeer op deze technologische convergentie als wel op de integratie tussen verschillende diensten en, als resultaat hiervan, verschillende markten.

Onder meer ontwikkelingen in multimedia hebben ervoor gezorgd dat verschillende diensten met diverse eigenschappen via dezelfde infrastructuur kunnen worden overgebracht; sterk in capaciteit en snelheid toegenomen telecommunicatienetwerken verzorgen de benodigde transmissie (zie ook Von Tunzelmann, 1999). Hierbij vervagen de grenzen tussen communicatiediensten (zoals bellen, mailen) en inhoudelijke diensten (zoals films of informatievoorziening). Een van de eerste publicaties waarin het begrip convergentie ruimer wordt omschreven dan convergentie in de zin van technologische integratie, is een green paper over de samensmelting tussen de dienstverlening van telecommunicatiebedrijven, mediabedrijven en IT-bedrijven uitgebracht door de Europese Commissie in 1997. In empirische studies naar dienstconvergentie wordt niet meer alleen gekeken naar de producenten van infrastructuur, maar vooral naar de gebruikers van deze infrastructuur en in het bijzonder naar multimediabedrijven die een belangrijke rol spelen in deze vorm van integratie (Von Tunzelmann, 1999). Dienstconvergentie stelt bedrijven in staat om voorheen moeilijk betreedbare, concurrerende markten te bedienen met geïntegreerde diensten. Het gaat hier om bestaande of licht gewijzigde diensten die op nieuwe markten worden aangeboden. Hierdoor groeien deze markten steeds meer naar elkaar toe. Voorbeelden hiervan zijn e-mail of internet via mobiele telefoons en televisie via internet, zoals op de website Uitzendinggemist.nl.

Naast deze marktconvergentie onderscheidt een aantal onderzoekers ook de mogelijkheid tot marktcreatie (zie bijvoorbeeld Greenstein en Khanna, 1997). Hierbij leidt dienstconvergentie niet alleen tot een versterking van bestaande dienstverlening in ontwikkelde markten maar ook tot de creatie van geheel nieuwe diensten in nog te ontwikkelen markten (zoals video-op-aanvraag). Marktcreatie onderscheidt zich dus van convergentie van bestaande markten, doordat iets geheel nieuws wordt ontwikkeld. Er is dan ook opbouw van nieuwe kennis nodig, terwijl bij convergentie van bestaande markten het eerder gaat om het combineren van bestaande kennis. 


\subsection{Het eerste decennium van de huidige eeuw: organisatorische convergentie}

Als gevolg van technologische convergentie en marktconvergentie ontstaan nieuwe strategische uitdagingen. In het eerste decennium van de huidige eeuw verplaatste de aandacht van onderzoekers zich dan ook steeds meer naar de strategieën die bedrijven gebruiken om te concurreren in convergerende markten waar de regels voor concurrentie in de afgelopen jaren sterk aan verandering onderhevig zijn geweest (Chan-Olmsted en Jamison, 2001; Wirtz, 2001; Borés et al., 2003; Christensen en Maskell, 2003; Bauer, 2005).

Chan-Olmsted en Jamison (2001) bijvoorbeeld bestuderen de strategieën die telecommunicatiebedrijven volgen om een sterke positie te verwerven in de convergerende telecommunicatie- en mediamarkten. $\mathrm{Zij}$ tonen aan dat telecommunicatiebedrijven de integrerende markten maar zelden betreden op basis van enkel en alleen hun eigen capaciteiten; de meeste telecommunicatiebedrijven gaan samenwerkingsverbanden aan met mediabedrijven. Op deze manier verkrijgen telecommunicatiebedrijven toegang tot de capaciteiten van mediabedrijven. Samen met hun mediapartners werken telecommunicatiebedrijven binnen samenwerkingsverbanden aan de integratie van hun dienstenpakketten en de ontwikkeling van geheel nieuwe diensten, evenals het opzetten van strategieën om klanten te voorzien van deze uitgebreide en nieuwe diensten (zie ook Borés et al., 2003). Een aantal auteurs (zie bijvoorbeeld Bauer, 2005) ziet in de sterke toename van het aantal samenwerkingsverbanden, als gevolg waarvan verschillende soorten bedrijven steeds meer naar elkaar toegroeien, een nieuwe golf van convergentie: organisatorische convergentie. Organisatorische convergentie is een belangrijk gevolg van technologische convergentie en marktconvergentie. Bauer (2005) definieert organisatorische convergentie als de bundeling van bedrijfsprocessen die voorheen in onafhankelijke bedrijven werden uitgevoerd. Hij benadrukt de belangrijke rol van allianties in convergentie. Allianties stellen bedrijven in staat om op effectieve wijze om te gaan met technologische convergentie en marktconvergentie. Er zijn verschillende vormen van allianties te onderscheiden die op basis van hun eigenschappen een specifieke rol zouden kunnen spelen in convergentie. In de volgende paragraaf beschrijven we deze verschillende typen allianties en hun mogelijke rol in marktconvergentie, waarbij zowel convergentie rondom bestaande diensten als marktcreatie wordt bestudeerd.

\section{De rol van verschillende typen allianties in convergentie tussen bestaande markten en creatie van nieuwe markten}

$\mathrm{Er}$ is in de afgelopen jaren een aantal artikelen verschenen dat de rol van samenwerking in convergentie beschrijft

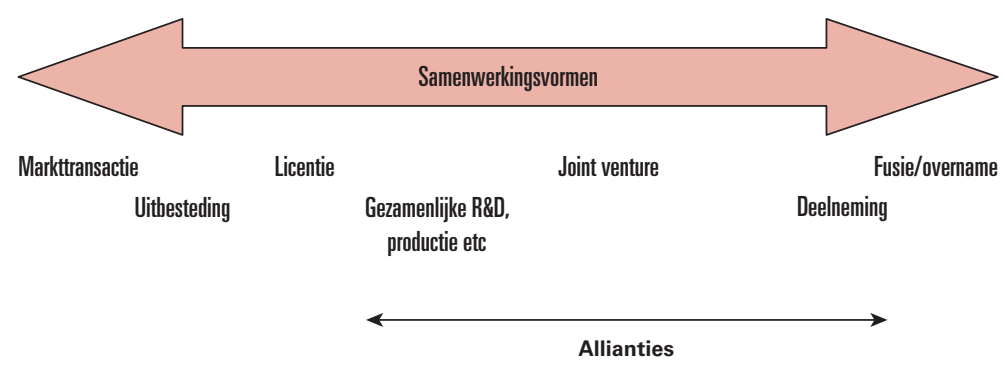

Figuur 1 Verschillende samenwerkingsvormen

(Chan-Olmsted en Jamison, 2001; Borés et al., 2003; Lee, 2007). Samenwerking tussen bedrijven kan vele vormen aannemen. De mogelijke samenwerkingsvormen kunnen worden ingedeeld op een continuüm van marktransacties met de laagste mate van integratie tot fusie en overname met de hoogste mate van integratie (De Man, 2006) (zie figuur 1).

Een veelvoorkomende samenwerkingsvorm is de alliantie. Allianties zijn samenwerkingsverbanden tussen bedrijven waarbij twee of meerdere partners met complementaire capaciteiten toewerken naar gezamenlijk vastgestelde, strategische doelstellingen (De Man, 2006). Kenmerkend voor allianties, ten opzichte van fusies of overnames, is dat de partners juridisch zelfstandige eenheden blijven. Het feit dat partners in een alliantie zelfstandig blijven, maakt het mogelijk een alliantie op veel verschillende manieren vorm te geven. Naast equity allianties zoals de joint venture, waarbij partners een nieuw bedrijf met een eigen management oprichten, en (wederzijdse) deelnemingen, kan een alliantie ook worden gerealiseerd door contractuele afspraken waarbij geen gezamenlijk eigendom wordt gecreëerd (non-equity allianties) (Williamson, 1975). Er bestaan ook minder vergaande samenwerkingsverbanden zoals uitbestedingsrelaties en licensing. Veel van deze relaties hebben echter het karakter van een transactie, waarbij van samenwerking nauwelijks sprake is.

Allianties worden onder meer ingezet voor het verkrijgen van toegang tot complementaire kennis en het gezamenlijk creëren van nieuwe kennis. Veel bedrijven hebben een toenemende kennisbehoefte en zijn niet meer in staat om alle benodigde kennis intern te ontwikkelen. Om sneller en met een beperkter risico toegang te krijgen tot een groot aantal kennisbronnen, gaan bedrijven in toenemende mate kennisallianties aan met hun partners. Verschillende typen kennisallianties stellen bedrijven in staat de noodzakelijke kennis samen met hun partners in kortere tijd te ontwikkelen of toegang te verkrijgen tot de al bestaande, complementaire kennis van hun partners. Zo hebben non-equity allianties veelal een kortetermijn- 
focus. Deze contractuele allianties kunnen snel worden opgestart en ook weer snel worden ontbonden. Op arm's length-basis gaan bedrijven een kortdurende relatie met elkaar aan, waarbij partners snel toegang krijgen tot elkaars' complementaire kennis. Equity allianties daarentegen hebben meestal een langeretermijnfocus. Door de investeringen die met deze typen allianties gepaard gaan, zijn partners voor langere tijd aan elkaar gebonden. Meestal werken partners binnen equity allianties op een intensieve manier samen, waarbij zij gezamenlijk nieuwe kennis ontwikkelen en op zoek gaan naar nieuwe mogelijkheden.

In de vorige paragraaf hebben we de verschillende vormen van convergentie, gekoppeld aan opeenvolgende tijdsperioden, beschreven. Technologische convergentie leidt tot dienstconvergentie, dienstconvergentie maakt marktconvergentie (convergentie tussen bestaande markten en de creatie van nieuwe markten) mogelijk, organisatorische convergentie is het gevolg van de manier waarop bedrijven omgaan met marktconvergentie. Een klein aantal auteurs heeft de relatie tussen marktconvergentie en organisatorische convergentie door middel van allianties bestudeerd (zie onder anderen Chan-Olmsted, 1998; Borés et al., 2003; Bauer, 2005). Zij stellen dat organisatorische convergentie een belangrijk gevolg is van marktconvergentie. Volgens Bauer (2005) is slechts een klein aantal bedrijven in staat om convergerende markten zelfstandig te bedienen. In de meeste gevallen hebben zij sterke partners nodig om toegang te verkrijgen tot complementaire kennisbronnen of om gezamenlijk de benodigde, nieuwe kennis te ontwikkelen. Binnen allianties kunnen samenwerkende bedrijven in een relatief korte tijdsperiode hun bestaande dienstverlening uitbreiden of nieuwe diensten ontwikkelen. Hierdoor zijn ze beter en sneller in staat om convergerende markten of nieuw gecreëerde markten te bedienen met de nodige geïntegreerde of nieuwe diensten (Chan-Olmsted, 1998; Borés et al., 2003). Door de toename van allianties die door bedrijven gebruikt worden om op effectieve wijze om te gaan met marktconvergentie, wordt organisatorische convergentie een feit. Onze eerste onderzoeksvraag is dan ook of telecom- en mediabedrijven ook allianties gebruiken om de benodigde convergentie te realiseren.

Uit de beschreven literatuur blijkt dat allianties een belangrijke rol spelen in de convergentie tussen bestaande markten en de creatie van nieuwe markten. Weinig tot niets is bekend over het belang van verschillende typen allianties, dat wil zeggen equity allianties en non-equity allianties, die bedrijven gebruiken om convergerende markten en nieuwe markten te bedienen. Het lijkt voor de hand te liggen dat bedrijven vooral non-equity allianties aangaan om op effectieve wijze het hoofd te bieden aan convergerende markten. Via non-equity allianties kunnen zij snelle toegang verkrijgen tot de complementaire kennisbasis van hun partners. Die kennis kunnen zij dan gebruiken om hun bestaande dienstverlening snel uit te breiden of te versterken. Klanten in convergerende markten kunnen vervolgens bediend worden met deze geïntegreerde diensten. Toegang tot complementaire kennis vraagt niet om intensieve samenwerking (Grant en Baden-Fuller, 2004). Het is voldoende om de bestaande kennisgebieden aan elkaar te koppelen. Een voorbeeld is de samenwerking tussen T-Mobile en Hyves, die als een van de eersten in Nederland experimenteerden om e-mail en internet via de mobiele telefoon te brengen. Hyves' diensten kwamen deels mobiel beschikbaar. Een ander voorbeeld is UPC, die door samenwerking met Telez Eredivisie voetbal op de digitale televisie bracht.

Dit ligt anders bij marktcreatie. Daar moeten echt nieuwe vaardigheden worden opgebouwd, wat om intensieve en langdurige kennisuitwisseling vraagt en hogere mate van control (Van der Meer-Kooistra en Vosselman, 2009). Dit zou beter plaats kunnen vinden in equity allianties. De creatie van geheel nieuwe kennis, nieuwe diensten en nieuwe markten lijkt dan ook vooral gerelateerd te zijn aan samenwerking door middel van equity allianties. Een voorbeeld is de joint venture DAG van PCM en KPN, waar een geheel nieuw type crossmedia krant werd ontwikkeld. Doordat partners binnen equity allianties op intensieve wijze langdurig met elkaar samenwerken, zijn zij veelal goed in staat om op gezamenlijke basis nieuwe mogelijkheden te benutten en/of te creëren. Onze tweede onderzoeksvraag is derhalve in welke mate er bij Nederlandse telecom- en mediabedrijven sprake is van convergentie rondom bestaande diensten of van marktcreatie. De derde onderzoeksvraag is of deze twee vormen van convergentie ook met andere typen allianties worden vormgegeven. Wij verwachten dat non-equity allianties een belangrijke rol spelen in convergentie tussen bestaande markten, terwijl equity allianties een rol spelen bij marktcreatie.

\section{Sectorale achtergrond: de wederzijdse afhankelijkheid van telecommunicatie- en mediabedrijven ${ }^{1}$}

De context waarbinnen we de rol van allianties in convergentie analyseren is de telecommunicatie- en media-industrie. Zoals al eerder beschreven, hebben technologische ontwikkelingen, in het bijzonder digitalisering, een belangrijke invloed uitgeoefend op de toenemende mate van convergentie tussen deze industrieën. Digitalisering heeft ervoor gezorgd dat verschillende diensten via dezelfde infrastructuur kunnen worden overgebracht en dat een bepaalde dienst kan worden verspreid via verschillende infrastructuren. Deze invloedrijke ontwikkelingen 
hebben geleid tot een hoge mate van complementariteit tussen telecommunicatiebedrijven en mediabedrijven. In figuur 2 wordt deze wederzijdse afhankelijkheid tussen de telecommunicatie- en media-industrie weergegeven.

\section{Figuur 2 Wederzijdse afhankelijkheid tussen telecommunicatie- en mediabedrijven}

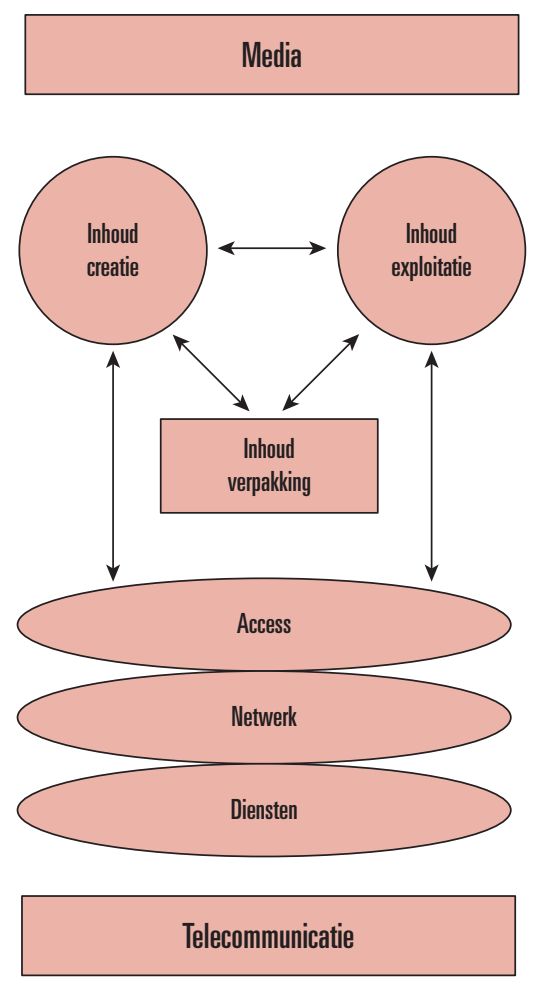

Zoals in figuur 2 is angegeven, voeren mediabedrijven drie belangrijke kernactiviteiten uit:

- zij creëren interessante inhoud zoals films, televisieprogramma's, krantenartikelen, boeken, muziek, informatie op het internet, enzovoort;

- zij bundelen (verpakken) deze inhoud tot waardevolle diensten voor de klant;

- zij exploiteren deze inhoud doordat zij met hun diensten de juiste markten bedienen.

Aangezien het creëren van inhoud een zeer tijdsintensief, arbeidsintensief en kapitaalintensief proces is, zijn mediabedrijven altijd op zoek naar manieren om de exploitatie van hun diensten te verbeteren. Dit wordt onder andere gedaan door het aanbieden van een dienst aan een breder publiek via verschillende infrastructuren. Zo verspreidt een aantal kranten tegenwoordig nieuwsflitsen via het internet en bieden zij nieuwsdiensten aan die klanten via hun mobiele telefoon kunnen raadplegen. Teneinde hun diensten te kunnen aanbieden via verschillende kanalen hebben mediabedrijven behoefte aan gedeelde, gemakke- lijk toegankelijke infrastructuur die meestal beheerd en gemanaged wordt door telecommunicatiebedrijven.

Ook voor de telecommunicatiebedrijven geldt dat zij in toenemende mate afhankelijk zijn geworden van de complementaire kennis van mediabedrijven. In de afgelopen jaren is de telecommunicatiemarkt in rap tempo verzadigd geraakt, waardoor telecommunicatiebedrijven een sterke behoefte hebben aan uitbreiding van hun bestaande diensten en de creatie van geheel nieuwe diensten. Daartoe hebben telecommunicatiebedrijven veel inhoud nodig. Hoewel een aantal telecommunicatiebedrijven heeft geprobeerd zelfstandig nieuwe inhoud te creëren (bijvoorbeeld KPN met Sport7), is dit niet erg succesvol gebleken. Het ontwikkelen van inhoud behoort dan ook niet tot de kernactiviteiten van telecommunicatiebedrijven.

Telecommunicatiebedrijven houden zich vooral bezig met het ontwikkelen, beheren en managen van (inmiddels) multifunctionele infrastructuur, waarmee zij toegang verschaffen tot inhoud en deze inhoud verspreiden. Zoals weergegeven in figuur 2 bestaan de infrastructurele capaciteiten van telecommunicatiebedrijven uit het beheren van apparatuur die toegang verschaft tot inhoudelijke diensten (modems), het ontwikkelen en managen van fysieke netwerkcomponenten die zorgen voor distributie van inhoud (coax, koper, glasvezel, ethernetwerken) en het configureren van diensten(pakketten) voor transmissie. Telecommunicatiebedrijven hebben mediabedrijven dus nodig om op basis van de ervaring van deze bedrijven met inhoudcreatie en inhoudexploitatie hun bestaande diensten uit te breiden en nieuwe diensten te ontwikkelen (zie figuur 2).

\section{Methodologie}

Voor onze analyse maken we gebruik van data over allianties tussen telecommunicatiebedrijven en mediabedrijven. De belangrijkste bron voor onze dataverzameling is het internet, waar we relevante persberichten, krantenartikelen en gespecialiseerde, sectorspecifieke tijdschriften op systematische wijze hebben doorzocht op belangrijke aankondigingen van allianties.

De definitie van alliantie omvat contractuele allianties, joint ventures (met verschillende aandelenverhoudingen) en minderheidsdeelnemingen van organisaties in elkaar. Bij de dataverzameling is gezocht op de volgende trefwoorden: samenwerking, partner, alliantie, joint venture, deelneming, content partner, gezamenlijke innovatie. Deze trefwoorden werden steeds gezamenlijk gebruikt met de naam van een telecombedrijf dat in Nederland actief is. De gevonden resultaten werden vervolgens beoordeeld om 
vast te stellen of hier inderdaad sprake was van een alliantie en niet van een inkooprelatie of fusie/overname.

In onze dataset zijn alleen allianties opgenomen die geïnitieerd zijn door Nederlandse telecommunicatiebedrijven gedurende de periode 2002-2007. Binnen een dergelijk samenwerkingsverband dient het telecommunicatiebedrijf samen te werken aan mediagerelateerde diensten met op zijn minst één mediapartner. Gedurende de bestudeerde periode waren 14 telecommunicatiebedrijven (zoals KPN en UPC) in Nederland actief. Daarnaast bevat onze dataset 88 andere bedrijven, het merendeel in de mediasector. In enkele multipartnerallianties waren ook IT-bedrijven vertegenwoordigd. Het totaal aantal allianties in onze dataset bedraagt 154 .

Van elke alliantie werd vastgesteld of het ging om een equity of een non-equity alliantie. Vervolgens werd vastgesteld wat de belangrijkste doelstelling van de alliantie was. Het kernonderscheid daarbij is of het ging om combinatie of doorontwikkeling van een bestaande dienst of om ontwikkeling van een nieuwe dienst. In het eerste geval werd de alliantie als zijnde gericht op convergentie van bestaande markten geclassificeerd; in het tweede geval gaat het om marktcreatie. De volgende paragraaf beschrijft de resultaten van dit onderzoek.

\section{Alliantievorming en convergentie tussen telecom en media}

In deze paragraaf onderzoeken we hoe telecommunicatiebedrijven en mediabedrijven convergeren door gebruik te maken van verschillende typen allianties, dat wil zeggen

\section{Figuur 3 Alliantieaankondigingen tussen telecommunicatie- en mediabedrijven}

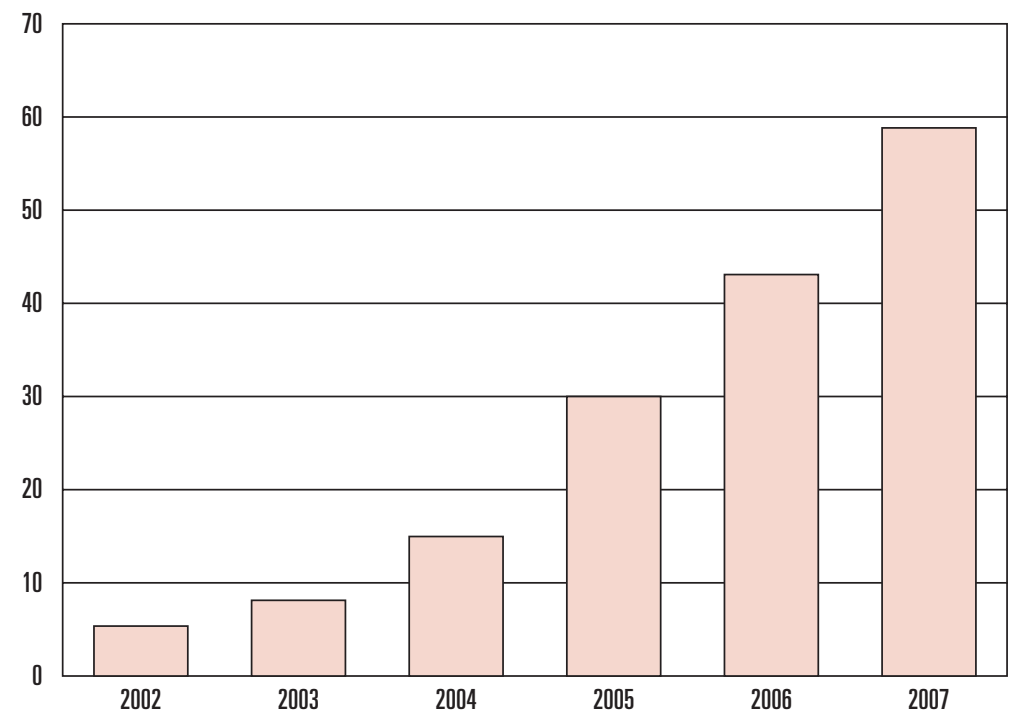

equity allianties en non-equity allianties. Een aantal grafieken en tabellen geeft de resultaten van onze analyses weer. Figuur 3 toont het jaarlijkse aantal alliantieaankondigingen tussen telecommunicatie- en mediabedrijven gedurende de periode 2002-2007.

Uit figuur 3 blijkt duidelijk dat het aantal nieuw afgesloten allianties tussen telecommunicatiebedrijven en mediabedrijven gedurende de onderzochte tijdsperiode sterk is toegenomen. In 2002 werden er in Nederland minder dan 10 nieuwe allianties gevormd tussen telecommunicatiebedrijven en mediabedrijven. In 2004 was dit aantal tot boven de 10 gestegen. In 2006 bundelden telecommunicatie- en mediabedrijven hun kennis in meer dan 40 nieuwe samenwerkingsverbanden. In 2007 werkten telecommunicatie- en mediabedrijven samen binnen ongeveer 60 nieuwe allianties. De groei in het aantal allianties tussen telecommunicatie- en mediabedrijven duidt op een toenemende mate van integratie tussen de infrastructurele kennisbasis van telecommunicatiebedrijven en de inhoudelijke capaciteiten van mediabedrijven. Onze eerste onderzoeksvraag kan dus positief beantwoord worden: Nederlandse telecom- en mediabedrijven gebruiken allianties om de convergentie tussen hun sectoren vorm te geven.

De tweede onderzoeksvraag betrof de typen convergentie: is er sprake van convergentie van bestaande markten of van marktcreatie? Een analyse van de verschillende motieven die aan de allianties in de telecommunicatie- en media-industrie ten grondslag liggen, laat het volgende zien (zie figuur 4). Figuur 4 laat zien dat $52 \%$ van alle nieuwe allianties tussen telecommunicatiebedrijven en

\section{Figuur 4 Doelstellingen van allianties tussen} telecommunicatie- en mediabedrijven

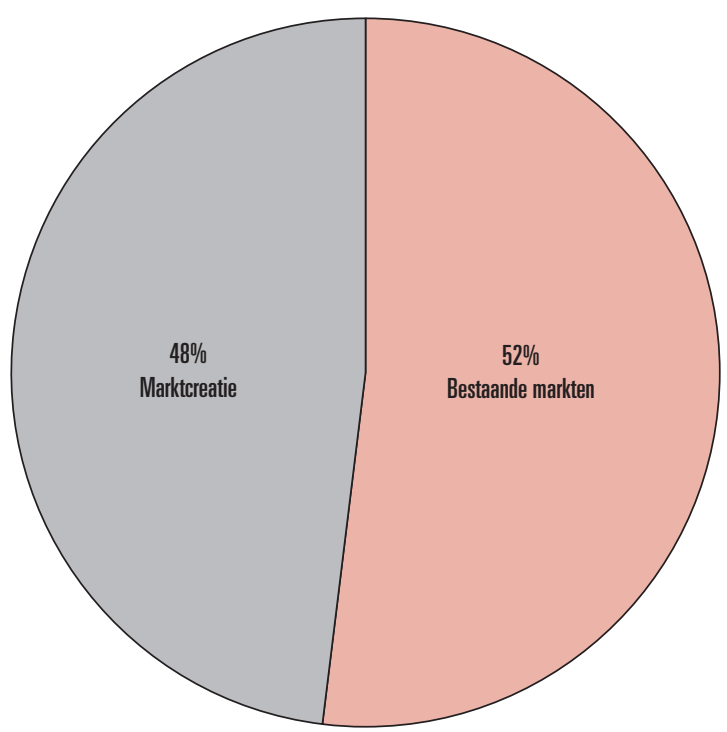


mediabedrijven, afgesloten gedurende de periode 20022007, wordt aangegaan rondom het combineren van bestaande of incrementeel gewijzigde diensten in nieuwe markten. Telecommunicatiebedrijven in onze steekproef die samen met mediabedrijven vooral werken aan de versterking en uitbreiding van hun huidige dienstenpakket zijn KPN, UPC, T-Mobile en Vodafone.

Circa $48 \%$ van alle nieuw afgesloten allianties tussen telecommunicatie- en mediabedrijven heeft marktcreatie als hoofddoelstelling. Telecommunicatiebedrijven zoals Casema, Essent en Multikabel (het huidige Ziggo), Telez en Versatel sluiten vooral allianties af met mediabedrijven met als belangrijkste doel het creëren van een volledig nieuwe markt. De conclusie voor onze tweede onderzoeksvraag is dus dat in het Nederlandse bedrijfsleven beide vormen van convergentie plaatsvinden, maar dat individuele bedrijven in hun strategie verschillende vormen van convergentie benadrukken.

Tabel 1 beschrijft de relatie tussen het gebruik van equity allianties en non-equity allianties en de motieven die bedrijven hebben om deze verschillende typen allianties aan te gaan. Het merendeel van de allianties tussen telecommunicatiebedrijven en mediabedrijven zijn nonequity allianties (87\%). Slechts $13 \%$ van de allianties betreft equity relaties. Voor zowel marktconvergentie rondom bestaande diensten als marktcreatie worden voornamelijk non-equity allianties gebruikt. Onze veronderstelling dat vooral flexibele, contractuele allianties worden gebruikt om convergerende, bestaande markten te bedienen met geïntegreerde diensten, wordt hiermee niet ondersteund. Ook voor marktcreatie worden non-equity allianties ingezet.

\section{Tabel 1 Relatie tussen motief en het gebruik van equity en non-equity allianties}

\begin{tabular}{|l|c|c|}
\hline & $\begin{array}{c}\text { Non-equity } \\
\text { alliantie }\end{array}$ & Equity alliantie \\
\hline Convergentie bestaande markten & $38 \%$ & $5 \%$ \\
\hline Marktcreatie & $49 \%$ & $8 \%$ \\
\hline
\end{tabular}

\section{Conclusies en implicaties}

Convergentie tussen Nederlandse telecombedrijven en mediabedrijven wordt gerealiseerd door het aangaan van allianties. Daarbij realiseren deze partijen zowel convergentie van bestaande diensten als convergentie rondom marktcreatie. Wel vinden we verschillen tussen partijen: sommige benadrukken de meer incrementele vorm van convergentie; andere partijen richten zich vooral op marktcreatie. Onze data geven geen indicatie dat er verschillende organisatievormen worden gebruikt om deze verschillende typen van convergentie te realiseren. Rondom beide vormen van convergentie zijn non-equity allianties de dominante organisatievorm.

Deze bevindingen roepen een aantal vragen op. Ten eerste is het interessant te onderzoeken wat de oorzaak is van het verschil in strategie tussen de partijen. Het is mogelijk dat de partijen die zich richten op convergentie rondom bestaande markten, marktcreatie vooral intern of door middel van fusie en overname realiseren. De op marktcreatie gerichte partijen zouden vooral de incrementele innovatie in huis kunnen doen. Het verschil in strategie kan zijn ontstaan doordat de partijen een andere uitgangspositie hebben ten aanzien van hun kennisbasis. Het is ook mogelijk dat zij de marktontwikkelingen anders inschatten en daarom andere richtingen kiezen.

Een tweede interessante vraag is waarom er weinig gebruik wordt gemaakt van equity allianties. In andere sectoren is dit overigens ook het geval (Duysters en De Man, 2003). Rondom marktcreatie moet nieuwe, gezamenlijke kennis worden opgebouwd, maar toch wordt ervoor gekozen dit niet te doen in één nieuwe joint venture. Wordt in een onzekere markt flexibiliteit belangrijker gevonden dan stabiele kennisopbouw? En zo ja, hoe organiseren bedrijven de opbouw van nieuwe kennis over organisatiegrenzen heen? Of is fusie en overname hier een alternatief? Een andere mogelijkheid is dat de volwassenheid van bedrijven met betrekking tot hun alliantiestrategie nog niet zo groot is. Dat zou kunnen verklaren waarom zij weinig differentiëren in het gebruik van hun allianties.

Theoretisch is de relatie tussen vormen van marktconvergentie en vormen van organisatorische convergentie van belang. Ons onderzoek laat zien dat allianties een rol spelen. De vraag is echter hoe stabiel die organisatorische convergentie is als die via allianties plaatsvindt. Allianties, en zeker non-equity allianties, zijn tijdelijke structuren. Wordt daarmee blijvende organisatorische convergentie bereikt? Of worden allianties op een later moment in andere organisatievormen omgezet? Of zijn de organisatorische consequenties van convergentie toch minder vergaand dan verwacht en kan worden volstaan met lossere verbanden tussen verder gescheiden sectoren?

Uit de voorgaande vragen blijkt al een beperking van ons onderzoek. Wij hebben alleen allianties bekeken. Nader onderzoek zou kunnen uitwijzen of en hoe andere organisatievormen zoals fusies en overnames of klantleveranciersrelaties worden ingezet om marktconvergentie te realiseren. Hoe verhouden zij zich tot equity en non-equity allianties? Wanneer wordt de keuze voor welke organisatievorm gemaakt? 
Ten tweede is onze studie alleen gebaseerd op de telecommunicatie- en media-industrie. Worden dezelfde resultaten gevonden in andere convergerende sectoren zoals biotechnologie en IT? Zijn er sectorale verschillen en zo ja, welke? Een laatste interessante vraag is of en hoe telecommunicatiebedrijven en mediabedrijven in staat zijn de verschillen die tussen hen bestaan, te overbruggen. Het gaat hier immers om compleet verschillende industrieën met verschillende culturen. Ook voor andere convergerende sectoren kan dit probleem spelen. Wat zijn op managementniveau de processen die moeten worden gebruikt om verschillen te overbruggen?
Dr. Nadine Roijakkers houdt zich bezig met onderzoek onderwijs en advies op het gebied van coöperatieve

innovatie aan de Universiteit Hasselt in België.

Prof. dr. Ard-Pieter de Man is hoogleraar Kennisnetwerken

en Innovatie aan de Vrije Universiteit Amsterdam en

organisatieadviseur bij Atos Consulting.

Ir. Ivo Gubbels is afgestuurd als Technisch Bedrijfskundig

Ingenieur aan de TU/e en werkzaam als Marketing

Consultant bij DSM.

\section{Noten}

1 Deze sectie is gebaseerd op Van Oranje et al.

(2008) en Atos Consulting (2009).

\section{Literatuur}

- Atos Consulting (2009), Telecom in 2015, Utrecht.

- Bauer, J. M. (2005), Bundling, differentiation, alliances, and mergers: Convergence strategies in U.S. communication markets,

Communications and Strategies, vol. 60, pp. 59-83.

- Borés, C., C. Saurina en R. Torres (2003), Technological convergence: A strategic perspective, Technovation, vol. 23, pp. 1-13.

- Bresnahan, T. en G. Saloner (1997), Large firms' demand for computer products and services: Competing market models, inertia, and enabling strategic change. In D.B. Yoffie (ed.), Competing in the age of digital convergence, Boston, MA: Harvard Business School Press. - Chan-Olmsted, S.M. (1998), Mergers, acquisitions, and convergence: The strategic alliances of broadcasting, cable television, and telephone services, Journal of Media Economics, vol. 11, pp. 33-46.

- Chan-Olmsted, S.M. en M. Jamison (2001), Rivalry through alliances: Competitive strategy in the global telecommunications market, European Management Journal, vol. 19, pp. 317- 331.

-Charles, D., P. Monk en E. Sciberras (1989), Technology and competition in the international telecommunications industry, London: Pinter.

- Chon, B.S., J.H. Choi, G.A. Barnett, J.A.

Danowski en S.H. Joo (2003), A structural analysis of media convergence: Cross-industry mergers and acquisitions in the information industries, Journal of Media Economics, vol. 16, no. 3, pp. 141-157.

- Christensen, J.F. en P. Maskell (2003), The industrial dynamics of the new digital economy, Cheltenham: Edward Elgar.

De Jonquieres, G. (1989), The deadly mirage of convergent technology, Financial Times, 24 July 1989.

Duysters, G.M. en A.P. de Man (2003), Transitory alliances: an instrument for surviving turbulent industries?, R\&D Management, vol. 33, no. 1, pp. 49-58.

- Duysters, G.M. en J. Hagedoorn (1998), Technological convergence in the IT industry: the role of strategic technology alliances and technological competencies, International Journal of the Economics of Business, vol. 5 , pp. 355-368.

- European Commission (1997), Green Paper on the convergence of the telecommunications, media, and information technology sectors and the implications for regulation-towards an information society approach, Brussels, 3 december 1997.

- Gambardella, A. en F. Malerba (1999), The organization of economic innovation in Europe, Cambridge UK: Cambridge University Press.

- Gambardella, A. en S. Torrisi (1998), Does technological convergence imply convergence in markets? Evidence from the electronics industry, Research Policy, vol. 27, pp. 445-463.

- Grant, R.M. en C. Baden-Fuller (2004), A knowledge accessing theory of strategic alliances, Journal of Management Studies, vol. 41, pp. 61-84.

- Greenstein, S. en T. Khanna (1997), What does industry convergence mean? In D.B. Yoffie (ed.), Competing in the age of digital convergence, Boston, MA: Harvard Business School Press.

- Jong, G. de en N. Kleijn (2009), Strategische en economische grondslagen van internationale joint ventures, Maandblad voor Accountancy en Bedrijfseconomie, vol. 83, pp. 392-404.

- Lant, T.K. en S.J. Mezias (1992), An organizational learning model of convergence and reorientation, Organization Science, vol. 3, pp. 47-71.

- Lee, G.K. (2007), The significance of network resources in the race to enter emerging product markets: the convergence of telephony communications and computer networking, 1989-2001, Strategic Management Journal, vol. 28, pp. 17-37.

- Man, A.P. de (2006), Alliantiebesturing: Samenwerking als precisie-instrument, Assen: Van Gorcum.

- McGahan, A., L. Vadasz en D. Yoffie (1997), Creating value and setting standards: The lessons of consumer electronics for Personal 
Digital Assistants. In: D.B. Yoffie (ed.), Competing in the age of digital convergence, Boston, MA: Harvard Business School Press. - Meer-Kooistra, J. van der, en E. Vosselman (2009), Accounting, beheersing en de opbouw van vertrouwen in uitbestedingsrelaties, Maandblad voor Accountancy en Bedrijfseconomie, vol. 83, pp. 301-308. - Porter, M. en V.E. Millar (1985), How information gives you competitive advantage, Harvard Business Review, vol. 63, pp. 149-160. - Van Oranje, C., J. Cave, M. Van der Mandele, R. Schindler, S.Y. Hong, I. lliev en I. Vogelsang (2008), Responding to convergence: Different approaches for telecommunication regulators, TR-700-OPTA, RAND report prepared for OPTA 30 September 2008

- Von Tunzelmann, N. (1988), Convergence of firms in information and communication: A test using patents data, mimeo, Brighton: Science Policy Research Unit.

- Von Tunzelmann, N. (1999), Technological accumulation and corporate change in the electronics industry. In: A Gambardella en F. Malerba (eds.), The organization of economic innovation in Europe, Cambridge: Cambridge University Press.
- Von Tunzelmann, N. en L. Soete (1987),

Diffusion and market structure with converging technologies, Research Memorandum,

Maastricht: University of Limburg.

- Williamson, O.E. (1975), Markets and hierarchies, London: The Free Press.

-Wirtz, B.W. (2001), Reconfiguration of value chains in converging media and communications markets, Long Range Planning, vol. 34, pp. 489-

506

Yoffie, D. (1997), Competing in the age of digital convergence, Boston, MA: Harvard Business School Press. 